\title{
A Survey of Educational Environment for the Accreditation of Audiology and Hearing Sciences Education
}

\author{
Jae Hee Lee ${ }^{1}$, Ji Young Lee ${ }^{2}$, Soo Jin Cho ${ }^{3}$, Sung II Park ${ }^{4}$, Jin-Dong Kim, \\ Mee-Hye Park ${ }^{6}$, Eun-Yeong Shin ${ }^{7}$, Jinsook Kim ${ }^{8}$ \\ 'Department of Audiology, Hallym University of Graduate Studies, Seoul, Korea \\ ${ }^{2}$ Department of Audiology and Speech-Language Pathology, Catholic University of Daegu, Gyeongsan, Korea \\ ${ }^{3}$ Department of Speech-Language Pathology \& Audiology, Nambu University, Gwangju, Korea \\ ${ }^{4}$ Department of Speech-Language Therapy and Aural Rehabilitation, Woosong University, Daejeon, Korea \\ ${ }^{5}$ Department of Speech and Hearing Therapy, College of Health Science, Catholic University of Pusan, Busan, Korea \\ ${ }^{6}$ Department of Speech-Language and Audiology, Kaya Univetsity, Gimmhae, Korea \\ ${ }^{7}$ Department of Speech-Language Pathology \& Audiology, Sehan University, Yeongam, Korea \\ ${ }^{8}$ Division of Speech Pathology and Audiology, Research Institute of Audiology and Speech Pathology, College of Natural Science, \\ Hallym University, Chuncheon, Korea
}

\author{
청각학 학과인증제를 위한 교육환경 조사 연구 \\ 이재희 ${ }^{1} \cdot$ 이지영 ${ }^{2} \cdot$ 조수진 $^{3} \cdot$ 박성일 $^{4} \cdot$ 김진동 ${ }^{5} \cdot$ 박미혜 ${ }^{6} \cdot$ 신은영 $^{7} \cdot$ 김진숙 $^{8}$ \\ 한림국제대학원대학교 청각학과 ${ }^{1}$, 대구가톨릭대학교 언어청각치료학과 ${ }^{2}$, \\ 남부대학교 언어치료청각학과 ${ }^{3}$, 우송대학교 언어치료청각재활학과 ${ }^{4}$, \\ 부산가톨릭대학교 보건과학대학 언어청각치료학과 ${ }^{5}$, 가야대학교 언어치료청각학과 ${ }^{6}$, \\ 세한대학교 언어치료청각학과 ${ }^{7}$ 한림대학교 자연과학대학 언어청각학부 · 청각언어연구소 ${ }^{8}$
}

\begin{abstract}
Audiologists are in a unique position to work with people who have hearing loss or any ear-related problems such as balance and tinnitus. The audiologists evaluate the hearing status, interpret the results, and plan the audiologic care and rehabilitation services. Due to a wide range of works as a professional, one of the most important roles of Audiology departments is to educate and train students to work as future professional audiologists. Given no establishment of accreditation of Audiology departments in Korea, a survey of academic and clinical education environments is a key starting point to discuss across departments for the process of the departmental accreditation. In the present study, a survey was conducted to obtain information about fourteen programs of academic and clinical environments offering the graduate or undergraduate degrees in the Audiology and Hearing Sciences. Aspects of core academic and clinical courses, environments of clinical education, information on professors and students were surveyed in this study. Results showed that most departments had the similar core courses. However, the departments varied in terms of clinical courses and facilities, and faculty members. Some strengths and weaknesses of each Audiology department were idetnfiied. Most of faculty agreed that the quality of education would be improved by developing endorsement for accreditation criteria and a common set of acceptable standards for universities. This would assure consistency across departments, education quality, better clinical and practical environments. The accreditation of audigology departments will promote the status of audiologists and hearing scientists in Korea, resulting in a high-quality audiological hearing services for the hearing-impaired. Future studies should be based on a regular monitoring of the departmental education.
\end{abstract}

Key Words: Educational environment, Accreditation of department of audiology, Department accreditation system.

Received: April 24, 2017 / Revised: June 23, 2017 / Accepted: June 30, 2017

Correspondence: Jinsook Kim, Division of Speech Pathology and Audiology, Research Institute of Audiology and Speech Pathology, College of Natural Science, Hallym University, 1 Hallimdaehak-gil, Chuncheon 24252, Korea

Tel: +82-33-248-2213 / Fax: +82-33-256-3240 / E-mail: jskim@hallym.ac.kr 


\section{INTRODUCTION}

현대 사회는 인구의 고령화, 산업화에 따른 소음의 노출, 각 종 질병과 사고, 약물의 오남용 등으로 인해 난청 인구가 해마 다 증가하고 있다. 따라서 이러한 난청인에 대한 상담 및 평가, 보장구의 적합, 청능훈련 및 사후관리 등을 전문적으로 담당 하는 청능사의 역할 또한 중요해지고 있다. 청각학(audiology) 은 청각 및 청력손실, 평형기능과 관련된 분야를 전문적으로 다루는 학문으로 기존의 청각 과학(hearing science)이나 이과 학 외에도 언어 재활학, 특수 교육학, 심리 음향학, 전자 공학 등 의 여러 학문 분야와 융복합하여 전문적인 학문으로 발전하였 다. 청능사(audiologist)는 청각학을 기반으로 청각 관리를 담당 하는 전문가로서 유럽, 미국, 캐나다, 호주 등의 의료 선진국에 서는 유망한 전문가 직종으로 손꼽히고 있다.

우리나라에서는 1997년에 처음 청각학 연구 과정이 시작된 이후 1998년에 청각학 석사과정이 최초로 개설되었고, 2001년 에 청각학 학사 과정이 시작되었다. 20년이 지난 현재 총 8개의 교육 기관[가야대(김해), 남부대(광주), 대구가톨릭대(경산), 부산 가톨릭대(부산), 세한대(영암), 우송대(대전), 한림국제대학원대 (서울), 한림대(춘천)]에서 청각학 교육 과정을 운영 중이다. 학 생들은 위의 4년제 학부 또는 대학원 과정을 통해 청각학 이론 과 실습 과정을 이수하게 된다. 졸업 후 청능사 자격검정원에서 관리하는 청능사 자격 시험에 응시하여 자격증을 취득할 수 있 으며, 청능사 경력이 7년 이상이고 매년 20시간 이상의 보수교 육을 충실하게 받은 경우 자격 심의를 거쳐 전문청능사 자격증 을 수여받을 수 있다.

청능사로서 주로 근무하는 환경으로는 보청기 센터 및 청능 재활 센터, 종합병원 혹은 개인병원(이비인후과), 보청기 및 청 각 관련 기기 제조사, 인공와우 제조사, 대학교 및 산업의학 연 구소, 음향기기 관련 연구소 등이 있다. 이와 같이 청능사는 다 양한 환경에서 청각 평가, 청각 보조기기(보청기, 인공와우 등) 의 적합, 청능 훈련 및 상담 등 전반적인 청능 재활을 주로 담 당하며, 그 외에 청각학 분야의 교육 및 기타 관련 서비스를 제 공하거나 제조, 연구 등의 다양한 직무를 수행하게 된다.

국내에서 보다 자격이 있는 청능사를 배출하기 위해서는 전 국 청각학 교육 기관에서 어떠한 교육 환경을 통해 이론 및 실 습 교육을 제공하고 있으며, 학생에게 전문적 지식을 전달하는 교수진의 전공 일치 및 자격증 취득 여부, 졸업 후 학생들의 취 업 현황 등을 조사할 필요가 있다. 교육 기관 자체에서 청능사 라는 전문가를 교육할 준비가 충분히 이루어지지 않았다면 양 과 질면에서 전문화된 청능사를 양성할 것을 기대하기 어렵기 때문이다. 국내 언어치료(언어병리 혹은 언어재활) 학과의 경우 대학원, 학부, 전문대학을 대상으로 설문조사를 하여 교육시설
및 장비, 학생, 교수진에 대한 내용을 분석하여 학과 인증제를 위한 기초 연구로 사용한 바 있다(Kwon et al., 2010).

해외에서 청각학 전문가는 약 $47 \%$ 가 대학원 졸업 기준이고 약 $27 \%$ 가 학부 졸업 기준으로 입문하는 전문가의 위상으로 구 성되는데, 이 부분은 선진국과 개발도상국 간 전문가의 교육수 준에 차이가 있는 것으로 나타났다(Goulios \& Patuzzi, 2008). 이 중 아시아권을 먼저 살펴보면, 중국의 경우 홍콩대학에 1996 년에 청각학 석사 과정과 2000년에 West China Medical School 내에 대학원 과정을 개설하였고, 타이완에서는 Wayne State University에서 4년제 청각학과를 개설하였다. 인도의 경우 청 각학 교육이 비교적 활발한 편인데, 정부주도의 협회인 All India Institute for Speech \& Hearing에서 언어와 청각분야의 교육을 주도하여 다양한 학사, 석사, 박사과정에서 관련 전문가 를 육성하는 교육을 하고 있다. 일본은 청각학 교육을 언어-청 각사(speech-language-heaing-therapist) 전문가를 육성하는 $2,3,4$ 년제의 학부과정에 포함하여 실시하고, 다양한 의사소통 장애와 청각장애분야에서 전문가 활동을 하도록 하고 있다. 그 외 이집트는 이비인후과의사의 학위과정 내에 청각학 석사와 박사과정을 개설하고 있고 사우디아라비아는 최소 석사학위를 갖춘 전문가를 교육하고 있으며, 말레이시아는 4년제 학부과정 에서 청각학을 교육하고 있다(Lee, 2006).

유럽은 일반 청능사(general audiologist) 과정을 학부수준에 서 교육하는데 첫 3년간은 이론수업으로 마지막 1년은 실습수 업으로 교육하며, 교과목의 구성은 기초과학 $25 \%$, 의학 및 진 단청각학 $25 \%$, 기술 및 환경청각학 $25 \%$, 심리, 교육, 직업, 의 사소통관련 청각학 $25 \%$ 로 이루어져 있다. 또한 일반 청능사는 의학, 물리, 교육학 등 다른 분야 교과목을 추가적으로 더 이 수할 경우 청각전문가(audiological specialist)로 근무할 수 있 다. 영국은 여러 대학(University of Manchester, University of Bristol, Aston University, University College of London 등)에 서 4년제로 청각학을 교육하고 있으며, 특히 NOVA Southeastern University에서는 post-baccalaureate doctorate in audiology $(\mathrm{AuD})$ 교육과정도 운영하고 있다. 프랑스에서는 University of Montellier에서 석사과정으로 청각학을 교육하고 있 으며, 이탈리아에서는 University of Ferrara에서 의과대학 학 생들이 advanced course in audiology의 실습 과정을 이수한 후 청각분야의 임상을 담당하고 있다. 스웨덴은 University of Göteborg에서는 학부과정으로, University of Lunds에서는 석 사 과정으로 청각학을 교육하고 있다(Moon, 2006).

미국은 청각학이 탄생한 국가이고 교육과 연구를 주도하는 종주국으로 그 탄생과정을 살펴보면, 세계 제 2 차 대전 중 증가 하는 청각장애인의 재활을 도와주기 위한 목적으로 시작되어 점차 학문적으로 체계화되었으며, 1939년에 "audiology, audi- 
ologist, audiological"이란 단어가 처음 생성되었고 1940년부터 뉴스에서 쓰이기 시작했으며 1945년에 대중적으로 사용되기 시 작하였다. 청능사(audiologist)는 미국 전역에서 인정된 전문직 업으로 "The Praxis Series of the Educational Testing Service (ETS)"에서 실시하는 자격시험에 합격하고 각 주의 행정적 절 차를 거쳐 전문가로 활동할 수 있으며 이러한 시험에 응시하기 위해서는 공인된 교육을 받아야 한다(Koo et al., 2006). 청각 학 교육은 학부 4년 이후 대학원에서 4년제로 운영되는 임상실 습이 강화된 $\mathrm{AuD}$ 과정으로 구성되어 있는데, 현재 미국 전역 총 75개 대학에서 $\mathrm{AuD}$ 과정이 개설되어 있다. 이와 별개로 박 사학위는 총 51 개 대학에 개설되어 청각학 관련 다양한 분야의 교육과 연구를 주도하고 있다. 공인된 청능사가 되려면 미국청 각위원회(American Board of Audiology)에서 주는 청능사 자 격증(Board Cerertification in Audiology)을 받아야 한다. 자격 증을 받기 위해 두 가지 요건이 필요하다. 인증된(accreditied) 교육기관에서 자격이 있는 청능사의 감독아래 2,000시간의 실 습 과정을 포함한 $\mathrm{AuD}$ 교육을 받는 것과 앞서 언급한 ETS에 서 실시하는 자격시험에 통과하는 것이다. 만일 인증되지 않은 교육기관에서 교육을 받으면 자격시험을 본 후 자격증을 받는 과정에서 학생이 받은 교육에 대한 검증자료를 제출해야 한다 (http://www.boardofaudiology.org/board-certified-in-audiology/). 또한 자격증을 유지하려면 3년에 60시간 보수교육을 받도록 하여 공인된 청능사의 질을 유지하고 있다. 이와 같이 American Speech-Language-Hearing Association (ASHA)에 서 일부분, 주로 American Academy of Audiology (AAA)에서 청능사 및 언어재활사를 양성하는 대학의 교과 과정, 실습 과정, 실습 환경, 교수진, 교육 환경 등에 대한 인증제를 관리하는 기 관을 따로 두어 Accreditation Commission for Audiology Education (ACAE)이라 명명하고 체계적으로 교육환경과 질을 관 리하고 있다.

그러나 국내의 경우 청각학의 학과 인증제가 도입되지 않았 으며, 이를 위한 기초 자료의 수집이 부족하다. 따라서 본 연구 를 통해 전국에 개설된 청각학과 교육 과정을 설문 조사하고 각 교육 기관의 청각학 교과 과정, 실습 과정 및 실습실 규모, 교수진 및 학생 정보를 정리 및 분석하여 학과 인증제에 대한 제언을 하고자 한다. 또한 이를 외국의 현황과 비교하여 국제적 인 청각학 교육의 수준을 위해 우리나라의 청각학 교육 여건 개선을 위한 제언을 하고자 하였다. 이 자료는 향후청각학과 학 과 인증제 도입의 기초 자료로 사용할 수 있으며, 보다 전문적 이고 우수한 청능사를 배출하고 청능사의 전문 능력을 강화하 는 데 도움이 될 수 있을 것이다.

\section{MATERIALS AND METHODS}

\section{설문지 제작}

국내 청각학과의 교육 환경 현황을 조사하기 위하여 국내 언 어치료학과의 학과 인증제 기초 연구 자료(Kwon et al., 2010), $\mathrm{AAA}$ 와 $\mathrm{ASHA}$ 에서 명시하는 교육내용 및 절차, 미국, 호주, 유 럽 등 국외 청각학과 인증 사례 등을 참고(Accreditation Commission for Audiology Education, 2016; Council on Academic Accreditation, 2017; Koo et al., 2006; Lee, 2006; Moon, 2006) 하여 네 가지 평가항목, 교과 과정 및 교과목 정보, 실습 과정 및 실습실 규모, 교수진, 학생을 통하여 교육 과정을 조사하였 다. 이 네 가지 항목에 대한 중요성과 내용은 청각학 교수협의 회의에서 수차례 회의를 거쳐 내용타당도를 검증하였으며 이를 정리하면 아래와 같다.

\section{교과 과정 및 교과목 정보}

청각학 전공 학생들은 학과 교과목을 이수하여 청능사에게 필요한 전문적인 지식을 습득하고 일정 시간 이상의 임상실습 을 거친 후 학위를 취득하여 청능사의 전문성을 준비하게 된 다. 청능사라는 전문적 직업에 부합하려면 청각 분야의 이론뿐 아니라 난청인을 대상으로 임상에서 평가, 재활, 상담 등을 할 수 있어야 하므로 교육과정에 있어 청각학 이론과 실습 교과목 의 개설이 매우 중요하다. 따라서 교육 기관에서 제공하는 교 과 과정 및 주요 교과목 이수 후 학생들이 청능사 자격을 받기 에 적절한지를 판단하기 위해 기관별 전공 필수 교과목과 전공 선택 교과목을 확인하고, 이 중 이론과 실습 과목의 비중을 나 누어 조사하였다. 구체적으로 각 학교의 교과목을 확인하였고, 이 중 이론과 실기 과목의 비중을 조사하였다. 또한 연간 교과 과정의 변화가 있을 수 있으므로 2014년 1학기부터 2016년 1학 기까지 최근 3년간의 정보를 취합하였다. 추가로 청능사자격검 정원에서 명시한 필수 교과목 중 몇 과목이 각 학교에서 개설 되고 있는지 확인하였다.

\section{교수진}

열악한 환경에서 학과를 운영할 경우 제대로 된 전문가를 양 성하는 것이 어려우며, 특히 교육기관에서는 교수진의 역할이 중요하다. 보다 질 높은 청각학 교육을 위해 청각학 전공 학생 에게 청능사로서 학습해야 할 전문 지식을 전달할 교수진이 청 각학을 전공하고, 청능사 자격증을 취득하고 지속적으로 유지 하고 있는 전문가이어야 한다. 선진국의 예를 볼 때, 학과 내의 전임 교원의 수가 최소 2 명 이상이며 특히 전공 필수 과목은 청 각학을 전공한 전임 교원이 맡는 것이 적절하다. 따라서 본 연 구에서 각 교육 기관에서 청각학 과목을 강의하는 전임 교원 
및 비전임 교원의 수를 조사하고, 각 교원이 담당하는 강의과 목 수와 학점을 확인하였다. 여기서 비전임 교원으로는 겸임 교 수, 초빙 교수, 강의전담 교수만을 포함하였고 시간 강사는 비 전임 교원으로 포함시키지 않았다. 보다 질 높은 청각학 교육을 위해 청각학 이론 및 실습 과목을 가르치는 전임 교원이 청각 학을 전공하였는지 전공 일치 유무를 확인하고, 전임, 비전임 교원 각각이 청능사 자격증을 취득하였고 지속적으로 유지하 고 있는지 여부를 조사하였다. 이는 교수 자질을 평가하는 목적 이 아니라 교수의 전공 일치와 자격증 유지 여부를 조사하여 양 질의 청각학 교육을 실시하는 데 목적을 두고 있다는 점을 설문 전에 검증한 후 조사를 시행하였다.

\section{실습 과정 및 실습실 규모}

청각학 전공 학생들이 졸업 후 청각학 분야에 취업하게 되면 난청인을 대상으로 임상에서 평가, 재활, 상담 등의 다양한 업 무를 시행하게 된다. 따라서 교육과정에 있어 실습 교과목의 개 설을 적절하게 하는지 이를 전임 교원이 담당하여 질 좋은 교 육을 제공하는지가 중요하다. 따라서 각 학교에서 개설하는 실 습 교과목의 총 개수를 확인하였고, 이 중 몇 개의 과목을 전 임 교원이 혹은 비전임 교원이 담당하는지 확인하기 위하여 각 교육 기관에서 어떠한 실습 과목을 필수 교과목으로 독립적으 로 개설하고 있는지 최근 3년간의 교과목을 조사하였다. 실습 과목명뿐만 아니라 실습 시간과 학점을 확인하여 적절하게 실 습을 진행하고 있는지 검토하였다. 또한 각 실습 과목을 청각 학과 전임 교원 혹은 비전임 교원이 담당하는지 조사하였고, 각 교육 기관의 실습실 규모를 조사하였다.

\section{학 생}

4년제 학부와 대학원은 신입생 모집 정원이 서로 다르고 기 관에 따라서도 서로 학생 수가 다르다. 각 학교별로 최근 3년간 신입생 모집 정원과 졸업생 중 청각학 전공 학생의 수를 조사하 였다. 또한 학과의 질을 결정할 수 있는 요건으로 학생들이 졸 업후 진로의 방향이나 취업률도 중요하므로 그 내용을 조사하 였다. 졸업 시의 취업률을 확인하기 위해 졸업생 중 청각에 관 련된 분야에 취업한 학생 수를 조사하였고, 어떤 분야에 취업 하는지 분야별 비중을 파악하였다. 청각학과 언어치료학 전공 을 함께 운영하는 경우, 청각학 전공을 따로 구분하여 조사를 시행하였다. 청능사는 난청인의 건강을 다루는 전문가이므로 전문적 지식을 습득한 후 자격증 취득 및 유지를 위해 지속적 으로 노력해야 한다. 따라서 졸업 이후 양질의 청능사의 배출로 확장되는지 확인하기 위해 대학별 자격증 시험 합격률과 청능 사 자격증을 취득한 학생 수 및 자격증 유지 학생 수도 함께 조 사하였다.

\section{자료 수집}

본 연구에서는 국내 4년제 대학교와 대학원(일반대학원 및 특수대학원)에 청각학 교육과정을 개설한 교육 기관에 설문을 요청하였다. 이에 해당하는 교육기관은 총 14 개로, 각 교육 기관 의 이름을 가나다순으로 열거하면 가야대학교(김해), 남부대학 교(광주), 남부대학교 특수대학원, 대구가톨릭대학교(경산), 대 구가톨릭대학교 일반대학원, 대구가톨릭대학교 특수대학원, 부 산가톨릭대학교(부산), 세한대학교(영암), 세한대학교 일반대학 원, 우송대학교(대전), 우송대학교 특수대학원, 한림국제대학원 대학교(서울), 한림대학교(춘천), 한림대학교 일반대학원이었다. 이 중 세한대학교 일반대학원의 경우 최근 3년동안 언어치료전 공만으로 운영되고 있어 설문에서는 제외하여 최종 조사기관 은 13 개 교육기관이었다.

설문에 앞서 본 설문의 목적과 절차를 설명하였고 각 교육 기 관에서 자발적으로 참여할 수 있게 하였다. 설문을 요청한 13 개 교육 기관 모두 본 연구의 설문에 참여하였다. 설문 작성은 각 학과의 청각학과 학과장 혹은 대표 교수가 엑셀에 직접 작성하 였다. 설문지를 통해서 조사한 구체적인 항목은 Appendix 1에 제시하였다. 연간 교과 과정의 변화를 반영하기 위해 최근 3년간 (2014년도 1학기와 2학기, 2015년도 1학기와 2학기, 2016년도 1 학기)의 자료를 기준으로 조사하였다.

\section{자료 검토 및 분석}

2016년 8 9월에 1차 자료 수집을 완료하였다. 2016년 10 11월 에 학과장(혹은 대표교수)이 보고한 1차 자료의 내용을 각 학과 별 홈페이지의 내용과 교차 점검하였고, 차이가 있는 경우 각 교육 기관의 학과장 혹은 대표 교수에게 직접 연락하여 설문 내용을 재차 확인하여 잘못 기재되거나 미기재된 자료에 대해 수정된 자료로 업데이트하였다. 2016년 11월 19일 전국청각학 교수협외희에서 설문 결과를 공개 발표하였고 각 학교의 대표 교수와 함께 토의하였다. 2016년 12월 28일 전국청각학교수협 의회 임원회의를 통해 내용을 수정하였고 고찰에 포함시킬 내 용, 학과의 기본 요건, 학과 인증제의 기준, 가칭 '학과인증위원 회의 설립 등에 대하여 논의하였다. 그 후 각 학교 정보 중 잘 못 기재된 정보에 대해 마지막 수정을 거쳤고, 2017년 1월에 최 종 자료를 정리한 후 본 연구의 결과로 사용하였다.

\section{RESULTS}

\section{청각학 전공 학교 및 학과 정보}

청각학 전공을 개설 중인 교육 기관을 설립년도에 따라 분류 하면 1997년에 “한림대학교 사회복지대학원" 내에 청각학전공 으로 가장 먼저 설립되었고 이 명칭이 2007년에 "한림국제대학 
원대학교”로 변경되었다. 2001년에 2개의 교육 기관에 학부 과 정이 개설되었고, 그 이후 2003년과 2005년에 1개교씩 설립되 었으며, 2006년에 3개교, 2010년과 2012년에 1개교씩, 2014년에 2 개교가 설립되었다. 지역별로 보면, 서울(1개교), 강원도(2개 교), 경상도(5개교), 전라도(4개교), 충청도(2개교)에 설립되어 있다. 학과명으로는 청각학과, 언어청각치료학과, 언어치료청각 학과, 언어치료-청각재활학과, 언어청각학부 청각학 전공 등의 이름을 사용하고 있으며, 각 대학별로 학과는 자연과학, 보건, 보건과학, 보건복지, 의료보건과학 계열 등에 속해 있다.

\section{청각학 전공 교과 과정 및 교과목 정보}

학교에 따라 다소 차이는 있었으나 4년제 학부의 경우 졸업 을 위해 130 154학점을 최소 이수 학점으로 요구하고 있으며, 석사 학위를 위한 대학원의 경우 보통 24 36학점을 최소 이수 학점으로 운영하고 있었다. 전공 필수 교과목의 경우 수가 많은 것이 중요하다기 보다는 어떠한 교과목들을 전공 필수로 운영 하고 있는지, 이론과 실습 과목의 비중은 어떤지가 더 중요하다 고 할 수 있다. Appendix 2는 최근 3년간 운영한 교과 과정 자 료를 기준으로 전국 대학별 “전공 필수” 교과목 총 개수와 총 교과목 중 이론 및 실습 과목의 비중을 보여준다. 표를 통해 알 수 있듯이, 4년제 대학의 경우 청각학 전공 필수 교과목의 수가 $1 \sim 13$ 개까지 다양하였다. 6 개의 학부 교육기관 중 대부분의 기관 에서 청각 관련 교과목만을 필수 교과목으로 포함하였으나(B, $\mathrm{E}, \mathrm{F}, \mathrm{I}, \mathrm{K}, \mathrm{M}$ 대학), $\mathrm{H}$ 대학의 경우 12 개의 청각학 전공 필수 교과목 중 단 2 개의 과목만 청각에 관련된 과목이었고 다른 필 수 과목은 언어 및 음성, 의사소통, 기타 교양(심리학, 생물학) 에 관련된 과목이었다. 대학원의 경우 필수 교과목의 수가 $5 \sim 16$ 개까지로 기관에 따라 필수 과목의 수가 달랐다. 모든 자 료를 종합하여 볼 때, 학부든 대학원이든 관계없이 전공 필수 교과목 중 실습 과목의 비중이 $40 \%$ 이상인 학교는 A 대학원, $\mathrm{E}$ 대학, J 대학원이었다.

Appendix 3에는 청각학 전공을 위한 전국 대학별 "전공 선 택" 교과목 총 개수와 이론 과 실습 과목의 정보를 제시하였다. 4년제 교육 기관의 경우 5 19개의 전공 선택 교과목을 운영중 이었고, 이 중 실습 과목이 3 6개가량 포함되어 있었다. 대학원 의 경우 기관에 따라 2 26개까지 다양한 수의 전공 선택 과목 을 개설하고 있었고 대부분 이론 과목에 치중되어 있었다. 실습 과목을 필수 교과목으로 운영하지 않았던 $\mathrm{B}$ 대학, $\mathrm{F}$ 대학, $\mathrm{K}$ 대학, L 대학원의 경우 실습 과목을 전공 선택 교과목으로 포 함하고 있음을 알 수 있다.

청각학 전공 학생의 경우 대부분 졸업 후 “청능사 자격증”을 취득하고 청능사의 직업을 가지기를 원한다. 현재 "청능사" 자 격증의 관리는 민간자격 등록기관인 청능사자격검정원에서 진
행하고 있으며 학부 혹은 대학원 과정에서 학사 이상의 학위를 취득한 후 청자원에서 지정한 분야의 교과목에서 지정한 최소 학점 이상을 반드시 이수하여야만 청능사 자격증 시험을 응시 할 수 있다.

최근 3년간 청능사자격검정원에서 인정하는 검정 과목 분야 는 총 4 분야로 기초청각학, 임상청각학, 재활청각학, 청각학 실 습으로 분류하였다. 기초청각학 분야에는 총 6 개의 교과목(청 각학개론, 청각해부생리, 심리음향, 언어병리학, 보건의료관련 법규, 연구방법론)을, 임상청각학 분야로는 총 8개의 교과목(일 반청각평가, 특수청각평가, 청각장애, 중추청각처리장애, 전정 기능장애, 아동청각학, 노인청각학, 산업청각학)을 재활청각학 분야로는 총 6 개의 교과목(보청기적합, 인공와우적합, 청각보 조기기, 청각재활, 청능훈련, 청각장애교육)을 인정하고 있다. 청각학 실습 분야는 8학점 이상으로 총 실습 시간 240시간 이 상(청능평가 60시간 이상, 보청기 및 인공와우 적합 80시간 이 상, 청능재활 60 시간 이상)을 이수하여야 한다. 현재의 분류체 계는 향후 청능사자격검정원의 운영관리 구조에 따라 다소 변 경 가능성도 있다.

Appendix 4는 현재 청능사자격검정원에서 지정한 과목 분야 (교과목)별로 전국 대학에서 개설 중인 교과목 정보를 보여준 다. 표를 통해 알 수 있듯이 각 학교에서 기초, 임상, 재활청각 학 분야의 교과목 대부분을 개설하여 운영하고 있었고 본 설 문 조사에 참여한 학교의 경우 청능사 자격증 시험 응시를 위 해 충분한 교육을 시행하고 있었다. 또한 청각학 실습 시간 인 정을 위해 최대 6 개까지 다양한 실습 과목을 개설하고 있었다.

\section{대학별 교수진 정보}

각 대학별 청각학 과목 중 전공 필수 교과목 수와 학점 그리 고 그 과목들을 담당하는 전임 혹은 비전임 교원의 정보를 확 인하였다(Appendix 5, 6, 7). 학교별 전공 필수 교과목 수와 이 를 담당하는 교원의 수를 확인한 결과, 대부분의 학교에서 교원 한 명당 약 2 3개의 필수 과목을 담당하는 비율을 가지고 있었 다. 13 개의 기관 중 $\mathrm{G}$ 대학원, $\mathrm{J}$ 대학원, $\mathrm{M}$ 대학은 1 명의 교원당 약 3 4개의 필수 과목을 담당하고 있어 타 교육 기관보다 한 교 원이 담당하는 필수 과목의 수가 많은 편이었다.

전공 필수 교과목을 담당하는 교원의 정보를 확인한 결과, $\mathrm{A}$ 대학원, $\mathrm{B}$ 대학, $\mathrm{F}$ 대학, $\mathrm{K}$ 대학, $\mathrm{L}$ 대학원은 전임 교원이 필수 교과목을 $100 \%$ 담당하고 있었다. C 대학원, D 대학원, G 대학 원, $\mathrm{H}$ 대학원, $\mathrm{M}$ 대학의 경우에서도 전임 교원이 필수 교과목 의 $50 \%$ 이상을 담당하고 있었다. 이 중 $\mathrm{E}$ 대학의 경우 전임보 다 비전임 교원이 전공 필수 교과목을 더 많이 담당하고 있었 으며, 전공 필수 교과목을 담당하는 교원 2명 또한 청각학을 전공한 교수가 아니었다. $\mathrm{H}$ 대학의 경우에서도 6 명의 전임 교 
원이 청각학 필수 교과목을 담당하고 있으나 단 1명만이 청각 학 전공 교수였다. I 대학과 J 대학원의 경우 전임 교원보다 비 전임 교원이 필수 과목을 더 많이 담당하고 있었으며, 한 명의 전임 교원 또한 청각학을 전공한 교수가 아니었다.

Appendix 8과 9는 대학별 전임 교원과 비전임 교원의 수와 각 교원이 담당하는 담당 과목의 학점을 보여준다. 각 교원의 청능사 자격증 상태도 중요하므로 학교별 전임/비전임 교원의 자격증 상태에 대한 정보를 함께 기입하였다. Appendix 8에 제 시하였듯이 $\mathrm{M}$ 대학의 경우만 제외하고 대부분의 전임 교원 모 두 청능사 자격증을 유지한 후 전문청능사를 취득한 상태였다. 그러나 학교마다 전임 교원의 수, 교원당 담당 과목의 학점에 차 이가 컸고 전임 교원 중 교원의 전공분야가 관련분야, 즉 언어 치료 전공이었던 교육기관이 3곳, 심리학 전공이 1곳으로 나타 났다. I대학의 언어치료 전공 교원은 청각장애언어재활이 세부 전공이었다. Appendix 9를 통해 알 수 있듯이, 비전임 교원의 수는 적게는 1 명부터 5 명까지 학교마다 달랐다. 비전임 교원이 연간 담당하는 과목을 살펴보면 대부분 6학점 이하였고, $\mathrm{E}$ 대 학, $\mathrm{F}$ 대학의 경우 최대 12 학점까지, $\mathrm{H}$ 대학과 I 대학의 경우 최 대 9학점까지, $\mathrm{M}$ 대학의 경우 최대 10학점까지 담당하고 있었다. $\mathrm{M}$ 대학의 비전임 교원은 청능사 자격증을 유지한 후 전문청능 사를 취득하였으나 비전임 교원은 청각학 전공 과목이 아닌 관 련 분야의 과목을 가르치는 경우가 다수 있으므로 모든 비전임 교원이 청능사 자격증을 취득 혹은 유지하고 있지는 않았다.

\section{대학별 실습 담당 교원 및 실습실 규모}

각 학교에서 개설하는 실습 교과목의 총 개수를 확인하였고, 이 중 몇 개의 과목을 전임 교원이 혹은 비전임 교원이 담당하 는지 확인하여 Appendix 8에 제시하였다. 표를 통해 알 수 있 듯이 각 학교에서 다양한 개수의 실습 과목을 개설하고 있었으 며 A 대학원과 $\mathrm{G}$ 대학원, $\mathrm{H}$ 대학의 경우 전임 교원이 $100 \%$ 실 습 과목을 담당하고 있었다. $\mathrm{E}$ 대학원의 경우 2 명의 전임 교원 이 실습 과목을 담당하고 있었으나 청각학 전공이 아닌 관련 분야 교수가 이를 담당하고 있었으며, $\mathrm{H}$ 대학원의 경우 1 명의 전임 교원이 3개의 실습 과목 모두를 담당하고 있었다. I 대학 과 J 대학원의 경우 비전임 교원만이 실습 과목을 담당하고 있 어 실습 과목을 담당하는 전임 교원의 비중은 학교마다 차이 가 컸다. $\mathrm{M}$ 대학의 경우에는 2 명의 전임 교원이 $60 \%$ 의 실습 과목과 1 명의 비전임 교원이 $40 \%$ 의 실습 과목을 담당하고 있 었다. 실습 과목이 보충 과목으로 분류되어 단독 실습 교과목 으로 분류되지 않은 경우, ' 0 '으로 표기되어 마치 실습 과목이 없는 것같이 나타났으나 실질적으로 실습을 실시하고 있었다. $\mathrm{C}$ 대학원의 경우에는 학부에 이미 개설된 실습 과목들은 대학 원에 중복하여 개설되지 않은 상황이었고, 대학원 과정에서 필
요 시 학부의 실습 과목을 수강할 수 있었다.

Appendix 9는 각 대학별 실습실 규모를 보여준다. K 대학과 $\mathrm{L}$ 대학원이 8개의 실습실에서 실습을 진행하고 있었으며, A 대 학원, $\mathrm{F}$ 대학, $\mathrm{G}$ 대학원에서는 4 개, $\mathrm{M}$ 대학에서는 3 개의 실습 실을 사용하고 있었다. B 대학, C 대학원, D 대학원, $\mathrm{E}$ 대학교 의 경우 실습실 한 개에서 모든 실습을 진행하고 있는 것으로 조사되었고, B 대학, C 대학원, D 대학원의 경우 실습실 규모가 비교적 큰 편이었다(40 50평 미만).

\section{대학별 학생 정보}

대학별 신입생 모집정원 학생 수와 전체 졸업생 중 청각학 전공의 학생 수가 대략 몇 명인지 파악하였다. 또한 전체 졸업 생 중 청각에 관련된 직종에 취업하는 학생의 수가 얼마나 되 는지를 파악하여 Appendix 10에 제시하였다. 표를 통해 알 수 있듯이, 학부와 대학원의 신입생 모집 정원에는 차이가 컸으며, 청각학과 언어치료학을 같이 운영하는 학과의 경우 학교마다 졸업생 중 청각학 전공의 학생 수와 청각 직종에 취업한 학생 수에 차이가 컸다. 먼저 청각학 전공만을 운영하는 A 대학원의 경우 청각학 전공 졸업생 비중과 청각학 분야로의 취업 학생의 비중이 가장 컸다. 그 외 L 대학원과 $\mathrm{G}$ 대학원, $\mathrm{M}$ 대학 또한 청 각학 전공 총 학생 수 중 청각관련 직종에 취업하는 학생의 비 중이 큰 편이었다. $\mathrm{H}$ 대학과 J 대학의 경우 청각 분야로 취업하 는 학생 수가 전체 졸업생 중 $10 \%$ 미만으로 적은 편이었다. B 대학의 경우 청각학 전공이 따로 구분됨 없이 학생들이 청각학 과 언어치료학(혹은 언어병리학)을 동시에 전공으로 하고 있었 다. Appendix 11은 위에서 조사한 청각관련 직종에 취헙한 학 생의 취업 분야를 보여준다. 매년 취업률이 다르므로 약 3년간 자료를 종합하여 확인한 결과, 병원, 보청기 회사, 개인 보청기 센터에 취업을 많이 하고 있었다. 마지막으로 청각학 전공 학생 으로서 졸업 후 청능사 자격증 시험을 응시한 경우 학교별로 합격율이 어떠한지, 청능사 자격증을 취득한 학생의 수 중 몇 $\%$ 나 자격증을 유지하고 있는지 조사하였다. 이 조사 결과는 청 능사자격검정원의 2017년 2월 자료를 기준으로 구성하였다. Appendix 12에 제시하였듯이, 각 학교마다 청능사 자격증 시험 합격률에 차이가 있었으며 $\mathrm{M}$ 대학을 제외하고는 $75 \%$ 이상의 합격률을 보였다. 청능사 자격증을 취득한 학생의 수 또한 학교 마다 차이가 컸는데, 이는 학교의 설립이 얼마나 오래되었는지 와 졸업생 수에 따라 큰 영향을 받으므로 단순히 이 수치가 크 게 중요하지는 않았다. 더 중요한 것은 청능사 자격증 취득 후 학생들이 자격증을 얼마나 유지하고 있는가 하는 점이다. 이를 조사한 결과 $60 \%$ 이상의 학생이 청능사 자격증을 유지하고 있 는 것은 A 대학원뿐이었다. B 대학의 경우 $39 \%$ 가량의 학생들 은 청능사 자격증을 유지하고 있었으며, 나머지 모든 대학은 청 
능사 자격즉 취득 학생 중 $30 \%$ 미만의 학생들만이 자격증을 유지하고 있었다. 전반적으로 자격증의 유지율이 저조한 편이 므로 자격증 취득 후 그 유지의 당위성에 대한 교육이 필요한 것으로 나타났다.

\section{DISCUSSIONS}

본 연구는 청각학을 교육하는 기관의 교수들의 참여로 이루 어졌고 설문 조사는 교과 과정 및 교과목 정보, 실습 과정 및 실습실 규모, 교수진, 학생에 대한 정보를 수집하는 데 목적을 두었다. 수집한 자료를 분석한 결과 위의 네 가지 항목 모두에서 각 학교마다 교육 환경이 다소 다른 것을 확인하였다.

교과 과정 및 교과목 정보를 살펴보면, 서로 다른 교과목명 을 사용하고 있어 학교 간 최대한 동일한 교과목명을 쓰는 것 이 필요하겠다. 각 학교에서 다양한 이론 교과목을 개설하고 있어 청능사자격검정원에서 시행하는 청능사 자격증 시험을 응 시하는 데 지장이 없었으나 실습 교과목의 개설 면에서는 학교 마다 차이가 컸다. 어떤 기관에서는 실습 교과목을 다양하게 구성하고 있었고 이를 필수 교과목으로 진행하고 있는 반면, 어떤 학교에서는 실습 교과목의 수가 충분하지 않고 이를 필수 과목이 아닌 보충 과목 혹은 선택 과목으로 운영하고 있었다. 또한 실습 교과목명으로 어떠한 실습을 위한 과목인지 명확하 여야 하는데 실습 I, II 등의 이름을 사용하여 정확히 어떤 내용 의 실습을 위한 과목인지 명확하지 않은 경우가 있으므로 이러 한 이러한 문제점들이 개선되어야겠다.

학생들은 청능사로서 전문적 지식을 습득할 뿐 아니라 적절 한 실습 과정을 이수하여 임상적 기술을 익혀야 한다. 따라서 이론 과목은 청각학을 전공한 전임 교원이 강의하고, 실습 교 과목은 현실적으로 청능사 자격을 유지하거나 전문청능사를 획득한 전문인이 살습을 담당하는 것이 교육의 질을 유지하는 데 가장 중요한 관점이라고 할 수 있다. 더욱이 해외의 교육이 나 $\mathrm{AuD}$ 학위과정에서도 실습의 중요성이 강조되고 있는 점을 고려할 때, 질 높은 실습 교육을 지도할 수 있는 교원에 대한 항목이 제도로 마련되어야 한다. 예를 들어 전임 교원이 실습 과목을 담당하는 것이 가장 적절하나 비전임 교원이 실습 과 목을 담당할 경우에 담당 비전임 교원은 청각학 전공자로 청능 사 자격증을 획득하고 유지하고 있는 전문가인지를 확인하는 절차가 필요하겠다.

또한 실습 환경 및 기자재를 충분히 확보하는 등 교육 환경 에 대한 지속적인 관리와 개선 노력이 필요하다. 본 조사에서는 학교별 실습실의 규모만을 제시하였으나 추후 실질적 학과 인 증 기준을 제시하고자 할 때는 학교별 실습 장비 보유율, 기자 재 종류 및 노후화 여부를 확인하는 절차가 추가되어야 한다.
각 장비에 대한 교정(calibration) 정보 또한 함께 확인하여야 한다. 그 외에 각 교육 기관에서는 실습에는 사용하지 않으나 기타 교육 및 연구를 목적으로 한 시설과 장비를 구비하고 있 을 수 있다. 이는 양질의 청능사 배출에 도움이 될 수 있으므로 이를 함께 조사하여 교육 기관 간 자료를 공유하는 것이 궁극 적으로 청각학의 학문적 발전에 도움이 될 수 있겠다.

기타 학문에서도 학과 인증을 위해 각 학과별 전임과 비전임 교원의 수, 전임과 비전임 교원의 강의 담당 비율 등을 기준으로 심사하고 있는데(Head \& Johnson, 2011; Hong, 2010; Kang \& Paek, 2005; Kwon et al., 2010), 청각학과 인증을 위해 이러한 항목에 대한 기준이 제시되어야 할 것이다. 본 연구에서 학교별 교수진에 대한 정보를 취합한 결과, 대부분의 학교에서 청각학 을 전공한 전임 교원이 2명 이상이고 필수 과목을 담당하고 있 었다. 이 중 몇 학교의 경우 청각학을 전공한 전임 교원이 없어 비전임 교원이 필수 과목을 담당하고 있거나 비전임 교원이 9 학점 이상을 담당하는 학교도 있었다. 우수한 전임 교원 확보를 통해 수준 높은 교육과정을 운영할 수 있으므로 교육의 질적 향상을 위해 향후 각 학교에서 외래 비전임 강사의 의존율을 낮 추고 충분한 전임 교원 확보를 위해 노력할 필요가 있다.

마지막으로 학생에 대한 정보를 분석한 결과, 학부와 대학원 간 청각학 전공 졸업생 및 취업생의 수에 차이가 컸다. 대학원 의 경우 청각학 전공자만을 주로 받는 경우가 많아 청각학 분 야의 취업으로 이어지는 경우가 많았다. 그러나 학부의 경우 청 각과 언어치료(언어병리) 전공을 함께 운영하는 경우가 많으므 로 비교적 청각학 전공 졸업생 수가 적었다. 또한 청능사라는 전문직을 위해 청능사 자격증의 취득 및 유지는 반드시 이루어 져야 하는 필수 절차인데 학생들 중 청능사 자격증을 유지하고 있는 비율이 비교적 저조하였다. 본 연구의 조사에 응답한 교육 기관 중 2 개의 교육기관을 제외하고는 자격증 취득 학생 중 $30 \%$ 이하의 수가 청능사 자격증을 제대로 유지를 하고 있는 실 정이어서 이 부분에 대한 개선도 절실해 보인다. 이를 위해 청능 사 자격증 시험 합격 후 보수교육에서 청능사 자격증 유지의 중 요성, 당위성, 필요성 등에 대한 교육을 보다 강화하는 것이 필 요하겠다. 특히 청능사 자격을 유지하여야 실습을 교육할 수 있 고 소속기관이 실습기관으로 인정될 수 있는 점 등에 대한 교육 과 홍보가 연계적으로 이루어져야 할 것으로 생각한다. 더불어 청능사자격검정원에서 수련교육시간과 보수교육비 등에 대한 비용의 하향 조정이 최근 있었고 민간자격증에 대한 긍정적 변 화도 이루어지고 있어 이러한 사항은 제도적 받침으로 개선될 것으로 생각한다.

결론적으로 본 연구를 통하여 청각학 교육여건 개선을 위해 서 학과인증에 필요한 인증평가요소와 배점 비중이 명시되어 야 할 것으로 나타났다. 청각학과 유사한 학문인 언어치료학과 
인증제를 위한 연구에서 제안한 인증평가 요소 및 배점을 참조 하여(Kwon et al., 2010) 청각학과 인증 평가에 필요한 분야 및 항목들에 대한 청각학전공교수협의회 회의를 진행하였다. 회의 결과와 본고의 저자들 의견을 수렴하여 Appendix 13과 같이 청 각학과 인증 평가 요소 및 배점을 제안하고자 한다. 본 제안에서 는 청각학 전공을 위한 교과 과정, 교육 환경, 학생 평가에 대한 분야를 각각 $20 \%$ 씩 배점하였고 교수진에 대한 배점 비중을 $40 \%$ 로 하였다. 다양한 해외 교육여건과 비교하였을 때(ACAE, 2016) 국내의 교육 과정, 우수한 교원 확보 등의 면에서 여전히 부족한 부분이 있으므로 이에 대한 배점 비중을 중요시하였다. 그 외에 각 항목에 대한 기준, 예를 들어 순음청력검사기, 중이 검사기, 청성유발전위평가 장비 등의 실습장비, 최소한의 전임 교원의 수, 실습실환경의 최소 단위 면적 등은 자격증 인증기관 인 청능사자격검정원과 논의하여 더 자세한 기준을 구체화 할 수 있을 것이다.

본 연구 자료는 청각학과 인증제의 도입을 위한 기초 자료로 사용할 수 있으며 인증 요소들과 학과 인증 평가 점수의 시행 에 구체적 기준은 청능사자격검정원과 청각학전공 교수들과의 협의로 결정해야 할 것이다. 또한 학과인증제를 시행할 경우 운 영에 대한 논의도 구체적으로 이루어져야 할 것으로 생각된다. 예를 들어 인증 점수가 70점 이하로 청각학 학과 인증이 안된 교육기관에서는 외국의 경우와 같이 자격증시험을 응시한 학 생들이 자격증을 받기 전에 수강한 과목, 교수진, 수강내역 등 을 보고하는 과정을 거쳐 검증을 해야 하거나, 학과 인증절차 는 3년 내지 5년 주기로 실시하여야 질적 수준이 유지하는 등 의 내용이 될 것이다. 청각학 교육의 발전을 위해 학과 인증제 의 진행은 신속히 이루어져야 할 것으로 생각되며, 실제 인증제 시행을 위해서 가칭 ‘학과인증위원회’ 등의 조직을 청능사자격 검정원 내에 두어 보다 구체적이고 타당한 절차를 모색하여야 하겠다.
전 세계적으로 인류의 청각건강을 담당하는 'audiologist'가 부족하다는 점이 밝혀진 바(Goulios \& Patuzzi, 2008) 청각학 분야는 앞으로도 지속적으로 발전할 것이다. 따라서 우리나라 도 청각학 교육의 질적 수준을 관리하여 국제적으로 손색이 없 는 선진국형 교육모델을 제시하여 국내외 청각건강분야를 담당 하는 청각 전문가를 양성할 수 있도록 하여야 한다. 이에 본고 의 연구결과와 제언이 국내 청각학의 발전에 초석이 되기를 바 라는 바이다.

중심 단어 : 교육 환경·청각학과 인증-학과 인증 시스템.

\section{REFERENCES}

Accreditation Commission for Audiology Education (2016, December 19). 2005 and 2016 ACAE Accreditation Standards. Retrieved from http:// acaeaccred.org/standards/.

Council on Academic Accreditation (2017, August 1). Standards for Accreditation of Graduate Education Programs in Audiology and Speech-Language Pathology. Retrieved from http://caa.asha.org/reporting/standards/2017standards/.

Goulios, H. \& Patuzzi, R. B. (2008). Audiology education and practice from an international perspective. International Journal of Audiology, 47(10), 647-664.

Head, R. B. \& Johnson, M. S. (2011). Accreditation and its influence on institutional effectiveness. New Directions for Community Colleges, 2011 (153), 37-52.

Hong, S. M. (2010). A study on the accreditation of social work education in Korea. Korean Journal of Social Welfare Education, 12, 123-145.

Kang, B. W. \& Paek, J. H. (2005). A comparative analysis of accreditation system among Korea, USA, and UK. Korean Journal of Comparative Education, 15(2), 1-32.

Koo, S. M., Kim, J. S., Lim, D. H., \& Lee, J. H. (2006). Current status of audiology in the U.S. Audiology, 2(1), 1-6.

Kwon, S. B., Kim, S. J., Pae, S. Y., Yoon, H. R., Hwang, M. A., \& Shin, M. S. (2010). A basic study for department of speech pathology certification with a focus on the educational environment. Journal of Speech and Hearing Disorders, 19(2), 1-23.

Lee, M. S. (2006). Audiologists and the current status of audiology in Asia. Audiology, 2(1), 17-21.

Moon, H. A. (2006). Current status of audiology in Europe. Audiology, 2(1), 7-10. 


\section{APPENDICES}

\section{Appendix 1. 청각학과의 교육 환경 조사를 위한 설문 항목}

"양질의 청능사를 배출하기 위해 학과에서 갖추어야 할 최적의 교육환경을 같이 고민하고자 하는 목적에 국내 청각학 학과 인증 제를 위한 교육 환경에 관해 설문조사를 진행하려고 합니다. 설문을 통해 전국 청각학 교육기관의 1) 교과과정 및 교과목 정보, 2) 실습과정 및 실습실 규모, 3) 교수진, 4) 학생에 대한 항목을 확인하고자 하며, 이는 청각학과 학과인증제의 도입을 위한 기 초자료로 사용할 예정입니다.

기본 정보 (학교명, 학교 주소, 학과명, 학과 소속 및 설립년도 등)

\section{1. 교과과정}

1) 학과의 교육 목표

2) 졸업을 위한 최소 이수학점 정보

3) 최근 3년간 실제로 개설한 청각학 전공 필수 교과목의 정보(교과목 명칭, 실습/이론 구분, 학점, 시수, 담당 교수의 정보 등을 자 세히 기입)

4) 최근 3년간 실제로 개설한 청각학 전공 선택 교과목의 정보(교과목 명칭, 실습/이론 구분, 학점, 시수, 담당 교수의 정보 등을 자세 히 기입)

5) 최근 3년간 실제로 개설하지는 않았으나 개설 예정인 교과목의 정보(교과목 명칭, 실습/이론 구분, 학점, 시수, 담당 가능한 교수 의 정보 등을 자세히 기입)

6) 청능사자격검정원에서 청능사 자격증 취득을 위해 명시하는 필수 교과목에 부합하는 교과목 정보(교과목을 담당하는 교수의 정 보 포함)

2. 실습과정 및 규모

1) 개설 중인 실습 교과목의 정보(교과목 명칭, 필수/전공 구분, 학점, 시수, 담당 교수의 정보 등을 자세히 기입)

2) 청각학 실습을 위한 임상실습실 규모

\section{3. 교수진}

1) 학과 내 전임 교원, 강의전담 교원, 비전임 교원의 수

2) 학과 내 청각학 전공의 전임 교원 혹은 강의전담 교원의 자세한 정보

(교원의 최종 학위 전공, 청각학 관련 경력이나 학위, 전임 혹은 강의전담 구분, 년간 담당하는 과목명, 년간 담당하는 과목 총 학점, 청능사 자격증이 있을 경우 자격증 번호 및 유효 만료일 등의 자세한 정보 기입)

3) 학과 내 청각학 과목을 강의하는 비전임 교원의 자세한 정보

\section{4. 학 생}

1) 최근 3년간 신입생 및 졸업생의 정보(졸업생의 중 청각학 전공 학생 수, 졸업생 중 청각학 관련 직종에 취업하는 학생)

2) 본교의 졸업생 중 청각관련 직종 분야에 취업한 경우, 취업 분야별 비중(최근 3년간 평균 자료 기입) 
Appendix 2. 대학별 청각학 전공 필수 교과목의 총 개수와 이론 및 실습 과목의 정보

\begin{tabular}{lccc}
\hline & $\begin{array}{c}\text { 청각학 전공 } \\
\text { 필수 교과목의 총 개수 }\end{array}$ & $\begin{array}{c}\text { 청각학 전공 } \\
\text { 필수 교과목 중 이론 과목의 } \\
\text { 개수[비중(\%)] }\end{array}$ & $\begin{array}{c}\text { 청각학 전공 } \\
\text { 필수 교과목 중 실습 과목의 } \\
\text { 개수[비중(\%)] }\end{array}$ \\
\hline A 대학원 & 9 & $4(44)$ & $5(56)$ \\
B 대학 & 1 & $1(100)$ & $0(0)$ \\
C 대학원 & 16 & $16(100)$ & $0(0)$ \\
D 대학원 & 12 & $10(83)$ & $2(17)$ \\
E 대학 & 9 & $5(56)$ & $4(44)$ \\
F 대학 & 2 & $2(100)$ & $0(0)$ \\
G 대학원 & 14 & $11(79)$ & $3(21)$ \\
H 대학 & 12 & $11(100)$ & $1(0)$ \\
I 대학 & 10 & $7(70)$ & $3(30)$ \\
J 대학원 & 9 & $5(56)$ & $4(44)$ \\
K 대학 & 10 & $10(100)$ & $0(0)$ \\
L 대학원 & 5 & $5(100)$ & $0(0)$ \\
M 대학 & 13 & $9(64)$ & $5(36)$ \\
\hline
\end{tabular}

Appendix 3. 대학별 청각학 전공 선택 교과목의 총 개수와 이론 및 실습 과목의 정보

\begin{tabular}{lccc}
\hline & $\begin{array}{c}\text { 청각학 전공 } \\
\text { 선택 교과목의 총 개수 }\end{array}$ & $\begin{array}{c}\text { 청각학 전공 선택 교과목 중 } \\
\text { 이론 과목의 개수[비중(\%)] }\end{array}$ & $\begin{array}{c}\text { 청각학 전공 선택 교과목 중 } \\
\text { 실습 과목의 개수[비중(\%)] }\end{array}$ \\
\hline A 대학원 & 16 & $16(100)$ & $0(0)$ \\
B 대학 & 19 & $16(84)$ & $3(16)$ \\
C 대학원 & 0 & $0(0)$ & $0(0)$ \\
D 대학원 & 2 & $2(100)$ & $0(0)$ \\
E 대학 & 8 & $8(100)$ & $0(0)$ \\
F 대학 & 19 & $13(68)$ & $6(32)$ \\
G 대학원 & 2 & $2(100)$ & $0(0)$ \\
H 대학 & 11 & $8(73)$ & $3(27)$ \\
I 대학 & 5 & $4(75)$ & $1(25)$ \\
J 대학원 & 17 & $17(100)$ & $0(0)$ \\
K 대학 & 19 & $13(68)$ & $6(32)$ \\
L 대학원 & 26 & $22(85)$ & $4(15)$ \\
M 대학 & 5 & $5(100)$ & $0(0)$ \\
\hline
\end{tabular}


Appendix 4. 청자원에서 인정하는 검정 과목 분야 중 대학별 개설 교과목 정보

\begin{tabular}{|c|c|c|c|c|}
\hline & \multicolumn{4}{|c|}{ 청자원에서 인정하는 검정 과목 분야 및 교과목 } \\
\hline & 기초청각학 분야 & 임상청각학 분야 & 재활청각학 분야 & 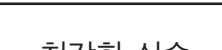 \\
\hline & 총 6개 교과목 & 총 8개 교과목 & 총 6개 교과목 & 성긱악 사ㄹㅡㅡ \\
\hline A 대학원 & 4개 개설 & 7개 개설 & 4개 개설 & 실습 과목 총 5 개 \\
\hline $\mathrm{B}$ 대학 & 4개 개설 & 6개 개설 & 4개 개설 & 실습 과목 총 3개 \\
\hline C 대학원 & 4 개 개설 & 6개 개설 & 4개 개설 & 실습 과목 총 0개 \\
\hline $\mathrm{D}$ 대학원 & 3 개 개설 & 5 개 개설 & 3 개 개설 & 실습 과목 총 2개 \\
\hline $\mathrm{E}$ 대학 & 3 개 개설 & 6 개 개설 & 6 개 개설 & 실습 과목 총 3개 \\
\hline $\mathrm{F}$ 대학 & 4 개 개설 & 7개 개설 & 4개 개설 & 실습 과목 총 6 개 \\
\hline G 대학원 & 4 개 개설 & 5 개 개설 & 4개 개설 & 실습 과목 총 3개 \\
\hline $\mathrm{H}$ 대학 & 3 개 개설 & 3개 개설 & 4개 개설 & 실습 과목 총 3개 \\
\hline | 대학 & 4개 개설 & 7개 개설 & 4 개 개설 & 실습 과목 총 4 개 \\
\hline J 대학원 & 3 개 개설 & 6 개 개설 & 5 개 개설 & 실습 과목 총 4 개 \\
\hline K 대학 & 5 개 개설 & 8개 개설 & 6 개 개설 & 실습 과목 총 6 개 \\
\hline L 대학원 & 5 개 개설 & 7개 개설 & 6 개 개설 & 실습 과목 총 4 개 \\
\hline $\mathrm{M}$ 대학 & 3 개 개설 & 7개 개설 & 4 개 개설 & 실습 과목 총 5 개 \\
\hline
\end{tabular}


151 Accreditation of Audiology Education

Appendix 5. 대학별 전임 교원의 정보

\begin{tabular}{|c|c|c|c|}
\hline & 전임 교원의 수(교원의 전공 분야) & 교원당 담당과목 학점 & 현재 자격증 종류와 유지 상태 \\
\hline A 대학원 & 4명(청각) & 21-24 학점 & $\begin{array}{c}4 \text { 명 모두 } \\
\text { 청능사 유지 + 전문청능사 }\end{array}$ \\
\hline $\mathrm{B}$ 대학 & 2명(청각) & 17-21 학점 & $\begin{array}{c}\text { 2명 모두 } \\
\text { 청능사 유지 + 전문청능사 }\end{array}$ \\
\hline C 대학원 & 2명(청각) & 6-12 학점 & $\begin{array}{c}2 \text { 명 모두 } \\
\text { 청능사 유지 + 전문청능사 }\end{array}$ \\
\hline D 대학원 & 2명(청각) & 3-9 학점 & $\begin{array}{c}\text { 2명 모두 } \\
\text { 청능사 유지 + 전문청능사 }\end{array}$ \\
\hline $\mathrm{E}$ 대학 & 2명(언어치료) & 9-18 학점 & $\begin{array}{c}1 \text { 명 } \\
\text { 청능사 유지 + 전문청능사 }\end{array}$ \\
\hline $\mathrm{F}$ 대학 & 2명(청각) & 20-24 학점 & $\begin{array}{c}2 \text { 명 모두 } \\
\text { 청능사 유지 + 전문청능사 }\end{array}$ \\
\hline G 대학원 & 2명(청각) & 17-21 학점 & $\begin{array}{c}2 \text { 명 모두 } \\
\text { 청능사 유지 + 전문청능사 }\end{array}$ \\
\hline $\mathrm{H}$ 대학 & 1명(청각) & 27 학점 & $\begin{array}{c}1 \text { 명 } \\
\text { 청능사 유지 + 전문청능사 }\end{array}$ \\
\hline | 대학 & 1명(언어치료) & 3 학점 & $\begin{array}{c}1 \text { 명 } \\
\text { 청능사 유지 + 전문청능사 }\end{array}$ \\
\hline $\mathrm{J}$ 대학원 & 1명(언어치료) & 3 학점 & $\begin{array}{c}1 \text { 명 } \\
\text { 청능사 유지 + 전문청능사 }\end{array}$ \\
\hline $\mathrm{K}$ 대학 & 5명(청각) & 12-18 학점 & $\begin{array}{c}\text { 5명 모두 } \\
\text { 청능사 유지 + 전문청능사 }\end{array}$ \\
\hline$L$ 대학원 & 5명(청각) & 6 학점 & $\begin{array}{c}\text { 5명 모두 } \\
\text { 청능사 유지 + 전문청능사 }\end{array}$ \\
\hline $\mathrm{M}$ 대학 & 2명(청각) & 16-28 학점 & $\begin{array}{c}\text { 2명 중 1명 } \\
\text { 청능사 유지 + 전문청능사, } 1 \text { 명 청능사 유지 }\end{array}$ \\
\hline
\end{tabular}




\section{Appendix 6. 대학별 비전임 교원의 정보}

\begin{tabular}{|c|c|c|c|}
\hline & 비전임 교원의 수 & 연간 담당과목 학점 & 현재 자격증 종류와 유지 상태 \\
\hline A 대학원 & 5명 & 1.5-3 학점 & 2 명 청능사 유지 + 전문청능사 \\
\hline $\mathrm{B}$ 대학 & 5명 & 2-6 학점 & 3 명 청능사 유지 + 전문청능사 \\
\hline C 대학원 & 2 명 & 3-6 학점 & 1 명 청능사 유지 + 전문청능사 \\
\hline $\mathrm{D}$ 대학원 & 4명 & 2-6 학점 & 3 명 청능사 유지 + 전문청능사 \\
\hline $\mathrm{E}$ 대학 & 4명 & 3-12 학점 & 2 명 청능사 유지 + 전문청능사 \\
\hline $\mathrm{F}$ 대학 & 2 명 & 9-12 학점 & 1명 청능사 자격증 유지 \\
\hline $\mathrm{G}$ 대학원 & 2 명 & 3 학점 & 1명 청능사 자격증 유지 \\
\hline $\mathrm{H}$ 대학 & 2 명 & 3-6 학점 & 1명 청능사 자격증 유지, 1 명 청능사 미취득 \\
\hline | 대학 & 3명 & 6-9 학점 & 2 명 청능사 유지 + 전문청능사, 1 명 청능사 자격증 취득 후 미유지 \\
\hline J 대학원 & 3명 & 6-9 학점 & 2 명 청능사 유지 + 전문청능사, 1 명 청능사 자격증 취득 후 미유지 \\
\hline $\mathrm{K}$ 대학 & 1명 & 0 학점 & 청능사 자격증 취득 후 미유지 \\
\hline$L$ 대학원 & 1명 & 0 학점 & 청능사 자격증 취득 후 미유지 \\
\hline $\mathrm{M}$ 대학 & 1명 & 10 학점 & 1명 전문청능사 \\
\hline
\end{tabular}

Appendix 7. 대학별 전공 필수 교과목의 총 개수와 이를 담당하는 전임/비전임 교원의 정보

\begin{tabular}{|c|c|c|c|}
\hline & $\begin{array}{c}\text { 전공 필수 교과목 } \\
\text { 총 개수/담당 교원 수 }\end{array}$ & $\begin{array}{c}\text { 전공 필수 교과목을 담당하는 } \\
\text { 총 교원 중 전임 교원의 수[비중(\%)] }\end{array}$ & $\begin{array}{c}\text { 전공 필수 교과목을 담당하는 } \\
\text { 총 교원 중 비전임 교원의 수[비중 }(\%)]\end{array}$ \\
\hline A 대학원 & 9개/4명 & 4명(100) & 0명(0) \\
\hline $\mathrm{B}$ 대학 & 1개/1명 & 1명(100) & 0명(0) \\
\hline C 대학원 & 16개/6명 & 4명(67) & 2명(33) \\
\hline D 대학원 & 12개/6명 & 3명(50) & 3명(50) \\
\hline $\mathrm{E}$ 대학 & 9개/5명 & 2명(20) & 3명(80) \\
\hline $\mathrm{F}$ 대학 & 2개/2명 & 2명(100) & 0명(0) \\
\hline $\mathrm{G}$ 대학원 & 14 개/3명 & 2명(67) & 1명(33) \\
\hline $\mathrm{H}$ 대학 & 12개/7명 & 6명(86) & 1명(14) \\
\hline | 대학 & 8개/4명 & 1명(25) & 3명(75) \\
\hline J 대학원 & 9개/3명 & 1명(33) & 2명(67) \\
\hline $\mathrm{K}$ 대학 & 10 개/5명 & 5명(100) & 0명(0) \\
\hline$L$ 대학원 & 5개/5명 & 5명(100) & 0명(0) \\
\hline $\mathrm{M}$ 대학 & 14개/3명 & 2명(67) & 1명(33) \\
\hline
\end{tabular}


Accreditation of Audiology Education

Appendix 8. 대학별 실습 교과목의 총 개수와 과목을 담당하는 전임 및 비전임 교원의 정보

\begin{tabular}{|c|c|c|c|}
\hline & $\begin{array}{l}\text { 실습 과목 총 개수/ } \\
\text { 담당 교원 수(개/명) }\end{array}$ & $\begin{array}{c}\text { 실습 과목을 담당하는 } \\
\text { 총 교원 중 전임 교원의 수[비중(\%)] }\end{array}$ & $\begin{array}{c}\text { 실습 과목을 담당하는 } \\
\text { 총 교원 중 비전임 교원의 수[비중(\%)] }\end{array}$ \\
\hline A 대학원 & $5 / 4$ & 4명(100) & 0명(0) \\
\hline $\mathrm{B}$ 대학 & $3 / 5$ & 2명(40) & 3명(60) \\
\hline C 대학원 & $0 / 0$ & 0명(0) & 0명(0) \\
\hline $\mathrm{D}$ 대학원 & $2 / 2$ & 1명(50) & 1명(50) \\
\hline $\mathrm{E}$ 대학 & $4 / 4$ & 2명(50) & 2명(50) \\
\hline $\mathrm{F}$ 대학 & $6 / 4$ & 2명(50) & 2명(50) \\
\hline G 대학원 & $3 / 2$ & 2명(100) & 0명(0) \\
\hline $\mathrm{H}$ 대학 & $3 / 1$ & 1명(100) & 0명(0) \\
\hline | 대학 & $3 / 3$ & 0명(0) & 3명(100) \\
\hline J 대학원 & $4 / 2$ & 0명(0) & 2명(100) \\
\hline $\mathrm{K}$ 대학 & $6 / 6$ & 2명(33) & 4명(67) \\
\hline L 대학원 & $4 / 4$ & 3명(75) & 1명(25) \\
\hline $\mathrm{M}$ 대학 & $5 / 3$ & 2명(60) & 1명(40) \\
\hline
\end{tabular}

Appendix 9. 대학별 실습실 규모

\begin{tabular}{|c|c|c|c|c|c|c|}
\hline & 실습실 총 수 & 10평 미만 & 10-20평 미만 & 20-30평 미만 & 30-40평 미만 & 40-50평 미만 \\
\hline A 대학원 & 4 & 2 & 2 & & & \\
\hline $\mathrm{B}$ 대학 & 1 & & & & & 1 \\
\hline C 대학원 & 1 & & & & & 1 \\
\hline $\mathrm{D}$ 대학원 & 1 & & & & & 1 \\
\hline $\mathrm{E}$ 대학 & 1 & & & & 1 & \\
\hline $\mathrm{F}$ 대학 & 4 & & & & 4 & \\
\hline G 대학원 & 4 & & & & 4 & \\
\hline $\mathrm{H}$ 대학 & 2 & & 1 & 1 & & \\
\hline | 대학 & 2 & & & 2 & & \\
\hline J 대학원 & 2 & & & 2 & & \\
\hline $\mathrm{K}$ 대학 & 8 & 7 & & 1 & & \\
\hline L 대학원 & 8 & 7 & & 1 & & \\
\hline M 대학 & 3 & & 3 & & & \\
\hline
\end{tabular}


Appendix 10. 대학별 신입생 모집정원과 졸업생 중 청각학 전공 학생에 대한 정보

\begin{tabular}{lccc}
\hline & 신입생 모집정원 & $\begin{array}{c}\text { 전체 졸업생 중 } \\
\text { 청각학 전공 학생 수와 비중(\%) }\end{array}$ & $\begin{array}{c}\text { 전체 졸업생 중 } \\
\text { 청각 관련 직종 취업 학생 수와 비중 }(\%)\end{array}$ \\
\hline A 대학원 & 25 & $25 / 25(100)$ & $23 / 25(92)$ \\
B 대학 & 40 & $*$ & $12 / 40(30)$ \\
C 대학원 & 10 & $4 / 10(40)$ & $4 / 10(40)$ \\
D 대학원 & 14 & $3 / 14(21)$ & $3 / 14(21)$ \\
E 대학 & 40 & $10 / 40(25)$ & $10 / 40(25)$ \\
F 대학 & 30 & $8 / 30(27)$ & $8 / 30(27)$ \\
G 대학원 & 10 & $2 / 3(67)$ & $2 / 3(67)$ \\
H 대학 & 57 & $29 / 57(51)$ & $5 / 57(9)$ \\
I 대학 & 57 & $22 / 57(39)$ & $22 / 57(39)$ \\
$J$ 대학원 & 27 & $2 / 27(7)$ & $2 / 27(7)$ \\
K 대학 & 70 & $36 / 70(51)$ & $27 / 70(39)$ \\
L 대학원 & 7.6 & $6 / 8(75)$ & $6 / 8(75)$ \\
$M$ 대학 & 32 & $22 / 22(100)$ & $16 / 22(72)$ \\
\hline
\end{tabular}

*청각학 전공의 구분 없이 청각학과 언어치료학을 동시에 전공으로 함

\section{Appendix 11. 취업한 총 학생 중 전공 관련 및 비관련 직종을 포함한 취업 분야별 수(명)}

\begin{tabular}{|c|c|c|c|c|c|c|}
\hline & Hospital & 보청기 회사 & 개인 보청기 센터 & 대학원 진학 & 기타 청각학 관련 직종 & 청각학 비관련 직종 \\
\hline A 대학원 & 10 & 30 & 50 & 5 & 1 & 4 \\
\hline $\mathrm{B}$ 대학 & 40 & 55 & 3 & 2 & & \\
\hline C 대학원 & 75 & & & & 25 & \\
\hline D 대학원 & 20 & & 80 & & & \\
\hline $\mathrm{E}$ 대학 & 14 & & 86 & & & \\
\hline $\mathrm{F}$ 대학 & 13 & 63 & 12 & & 12 & \\
\hline $\mathrm{G}$ 대학원 & & 100 & & & & \\
\hline $\mathrm{H}$ 대학 & 20 & 2 & 5 & 10 & & 63 \\
\hline | 대학 & 12 & 55 & 21 & 5 & & 7 \\
\hline $\mathrm{J}$ 대학원 & 50 & 50 & & & & \\
\hline $\mathrm{K}$ 대학 & 30 & 33 & 5 & 32 & & \\
\hline $\mathrm{L}$ 대학원 & 17 & 29 & 54 & & & \\
\hline M 대학 & 16 & 7 & 2 & 2 & 24 & 14 \\
\hline
\end{tabular}


18 Accreditation of Audiology Education

Appendix 12. 대학별 청능사 자격증 시험 합격률(최근2년 기준) 및 자격증 취득 및 유지 학생 수

\begin{tabular}{lccc}
\hline & 청능사 자격증 시험 합격률 $(\%)$ & 청능사 자격증 취득 학생 수 & 청능사 자격증 유지 학생 수 $(\%)$ \\
\hline A 대학원 & 85 & 76 & $46(61)$ \\
B 대학 & 82 & 150 & $59(39)$ \\
C 대학원 & - & - & - \\
D 대학원 & - & - & - \\
E 대학 & 75 & 185 & $48(26)$ \\
F 대학 & 79 & 129 & $32(25)$ \\
G 대학원 & - & - & - \\
H 대학 & 99 & 202 & $55(27)$ \\
I 대학 & 96 & 137 & $40(29)$ \\
$J$ 대학원 & - & - & - \\
K 대학 & 89 & 372 & $79(21)$ \\
L 대학원 & - & 45 & $13(29)$ \\
$M$ 대학 & 50 & 218 & $48(22)$ \\
\hline
\end{tabular}

Appendix 13. 청각학과 인증 평가 요소 및 배점 비중

\begin{tabular}{|c|c|c|c|}
\hline 분 야 & 항 목 & 백분율(\%) & Total $(\%)$ \\
\hline \multirow[t]{4}{*}{ 청각학 전공을 위한 교과 과정 } & 청각학 전공 이론 과목 & 5 & 20 \\
\hline & 청각학 전공 전임 교원의 이론과목강의 & 5 & \\
\hline & 청각학 전공 실습 과목 & 5 & \\
\hline & 자격증 유지자의 실습 과목강의(전문청능사혹은 청능사) & 5 & \\
\hline \multirow[t]{4}{*}{ 교육 환경 } & 실습실 환경 & 5 & 20 \\
\hline & 실습 장비 & 5 & \\
\hline & 실습 담당 교원의 자격증 유지 여부 & 5 & \\
\hline & 행정관련 지원(교육 및 실습조교) & 5 & \\
\hline \multirow[t]{4}{*}{ 교수진 } & 청각학 전공 전임 교원의 수 & 10 & 40 \\
\hline & 전임 교원의 전공 강의 시수 비율 & 10 & \\
\hline & 전임 교원의 자격증 유지 여부 & 10 & \\
\hline & 학술활동 여부 & 10 & \\
\hline \multirow[t]{4}{*}{ 학생 평가 } & 신입생 충원율 & 5 & 20 \\
\hline & 재학률 & 5 & \\
\hline & 자격증 합격 및 유지율 & 5 & \\
\hline & 청각학 분야 취업률 & 5 & \\
\hline
\end{tabular}

